\title{
A Detailed Bromination Study of 7-Hydroxy-4-Methyl Benzopyran-2-One Under Classical Method and Microwave Irradiation
}

Vijay D. Gangan ${ }^{* a}$, Ajaykumar C. Singh ${ }^{b}$, Ruchira Joshi ${ }^{b}$, Amod V. Tamhankarc, Kalpana J. Bhatwadekard, Shyamlal T. Yadava, Suyog S. Dayea, Dattatraya A. Dutea, Sakharam K. Godage ${ }^{a}$, Manoj Yewalea , Gaurav Pimple ${ }^{a}$ and Arjun L. Ghorpade

a.Department of Chemistry, Loba Chemie Pvt. Ltd.,. Plot No. D-22, M.I.D.C.. Tarapur, Boisar Palghar, Maharashtra, India

b.Department of Chemistry, R. D. National College, Bandra (West) Mumbai, Maharashtra, India

c. COO, N. S. Chemicals, 601, Devavrata, sector 17, Vashi Navi Mumbai Maharashtra, India

d.Technical Director, Sirmaxo Chemicals Private Limited, Plot No.:, E, 35, Palghar, Tarapur Road, Tarapur M.I.D.C., Boisar, Maharashtra, India

\section{ABSTRACT}

7-Hydroxy-4-methyl benzopyran-2-one, Benzopyran a class of coumarin derivative, has been subjected for bromination under classical method, microwave irradiation and solvent-free protocol for allylic and vinylic bromination using liquid $\mathrm{Br}$, organic bromides, $\mathrm{NBS}, \mathrm{HBr}-\mathrm{H}_{2} \mathrm{O}_{2}$ and $\mathrm{DDH}$ as brominating agent under different protic and aprotic solvents. The efficacy of the bromination of benzopyran under classical method and microwave irradiation has been established. The effects of the bromination and location of the substituents on the outcome of the reaction have been rationalized by using ${ }^{1} \mathrm{H}$ NMR and IR spectrum. Few of them showing promising antibacterial activity.

Keywords : Substituted Benzopyran, Classical Method, Microwave Irradiation, Protic and Aprotic Solvents, Allylic and Vinylic Bromination, ${ }^{1} \mathrm{H}$ NMR, TOF MS ES and Elemental Analysis.

\section{INTRODUCTION}

Benzopyran (coumarin) derivatives continue to be investigated over the years due to their importance to organic and medicinal chemists because of their huge biological activities ${ }^{1}$ (Kumar et. al., 2007). Benzopyran and its derivatives are associated with various functions viz. anti-inflammatory ${ }^{2}$ (Lin et. al., 2006), anti-convulsant ${ }^{3}$ (Bhat et. al., 2006), anti-viral ${ }^{4}$ (Massimo et. al., 2003), anticoagulant ${ }^{5}$ (Ruszat et. al., 2007), antioxidant ${ }^{6}$ (Tyagi et. al., 2003), antibacterial ${ }^{7}$ (Modranka et. al., 2006), antifungal ${ }^{8}$ (Sardari et. al., 1999), anti-HIV9a,b (Huang et. al., 2005), anticarcinogenic material and antihistamine activity ${ }^{10}$ (Elinos-Baez et. al., 2005). Apart from this, they are attracting considerable attention of chemists as a large number of natural products contain this heterocyclic nucleus and are widely used as additives $^{11}$ (Mohanty et. al., 1967) in food, perfumes, cosmetics, pharmaceutical ${ }^{12}$ (Kennedy et. al., 1997), optical brighterners (Zahradnik, 1990) in dispersed fluorescent and laser dyes ${ }^{13}$ (Murray et. al., 1982 and Bodenbender, 1912).

Bromination of organic (Natural) compounds continues to receive attention by research workers all over the world. The Bromination of carbonyl compounds is an important transformation in synthetic organic chemistry, bromination of side chain of aromatic ketones has attracted attention 
because the resulting bromo ketones are intermediates for the synthesis of variety of biologically active compounds. Bromination at 1- 8 is the first step of introducing a heteroatom so as to provide additional conjugation to the carbonyl group.

The research involves detailed study of bromination of certain benzopyrones. The various products formed have been analyzed and pathways of their formation are described. Bromo derivatives have wide utility both as products and intermediates. Bromination is one of the most important reaction process used for preparation of lead molecules for drugs and several of the pharmaceuticals. Thus by carrying out bromination studies we propose to enhance the synthetic utility of them.

In continuation to our earlier work ${ }^{14}$ (Gangan et. al., 2017) we have systematically studied the effect of various brominating agents under various protic and aprotic solvents. The efficacy of the bromination of benzopyran under classical method and microwave irradiation has been established.

Reaction Scheme :<smiles>Cc1cc(=O)oc2cc(O)ccc12</smiles>

S1

7-hydroxy-4-methyl -benzopyran-2-one
(1) Classical (Solvent + Brominating Agent + Heating)

(2) Microwave (Solvent + Brominating Agent + Heating)

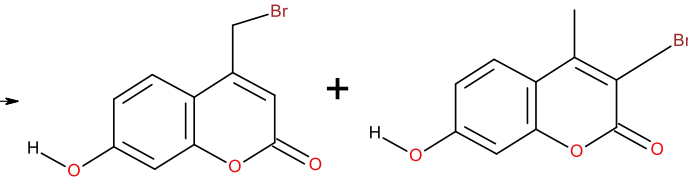

$1 a$

$1 b$

4-(bromomethyl)-7- 3-bromo-4-methyl-7hydroxy benzopyran-2- hydroxy-benzopyran-2-one one

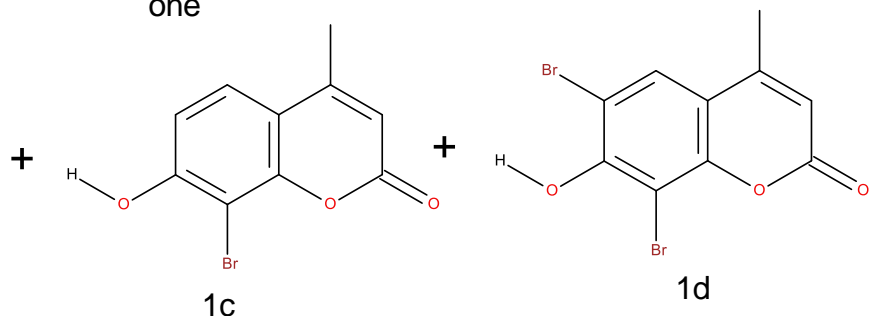

8-bromo-7-hydroxy-4methyl-Benzopyran-2-one

6,8-dibromo-7-hydroxy-4methyl-Benzopyran-2-one

\section{RESULTS AND DISCUSSION}

\section{General Procedure for Classical bromination of} substituted Coumarin ( Method A).

When $\mathrm{Br}_{2}$, NBS, DDH, $\mathrm{H}_{2} \mathrm{O}_{2}-\mathrm{HBr}$, TBATB, benzyl peroxide and AIBN (radical initiator) was thoroughly mixed stoicheometrically with the substrate in the presence of solvent and elevated temperature for the stipulated time and triturated with crushed ice, then depending on the stoichiometric proportion of brominating agent, the respective product was obtained as a filterable solid under suction and recrystallized from glacial acetic acid. The detailed results are summarized in Table 1.

\section{General Procedure for Microwave Irradiation}

\section{bromination of substituted Coumarin}

\section{(Method B).}

When brominating agent thoroughly mixed stoicheometrically with the substrate in the 
presence of solvent and elevated temperature under Microwave oven and heated at $620 \mathrm{~W}$ for the appropriate time (monitored by TLC): After completion, the reaction mixture was cooled to room temperature, poured into crushed ice, then depending on the stoichiometric proportion of brominating agent, the respective product was obtained as a filterable solid under suction and the detailed results are summarized in Table 1.

Table 1

\begin{tabular}{|c|c|c|c|c|c|c|}
\hline Entry & Substrate & Solvents & $\begin{array}{l}\text { Reaction } \\
\text { condition }\end{array}$ & \multicolumn{2}{|c|}{$\begin{array}{c}\text { Method A } \\
\text { (Classical) } \\
\text { Time Yields } \\
\text { (in Min.) (in\%) }\end{array}$} & $\begin{array}{l}\text { M.P. } \\
\left({ }^{0} \mathrm{C}\right)\end{array}$ \\
\hline \multirow[t]{6}{*}{1} & \multirow{6}{*}{ 7-hydroxy-4-methyl-benzopyron-2-one } & $\mathrm{CH}_{3} \mathrm{COOH}$ & 1 Eqv. $\mathrm{Br}_{2}$ & 45 & 43 & 246 \\
\hline & & $\mathrm{CH}_{2} \mathrm{Cl}_{2} / \mathrm{CH}_{3} \mathrm{COOH}$ & $\begin{array}{c}\text { 1Eqv. } \mathrm{HBr}- \\
\mathrm{H}_{2} \mathrm{O}_{2}\end{array}$ & 45 & 62 & 246 \\
\hline & & $\begin{array}{c}\text { THF / Ethyl } \\
\text { acetate/Acetonitrile }\end{array}$ & 1 Eqv. TBATB & 90 & 49 & 272 \\
\hline & & $\begin{array}{l}\text { Ethyl acetate/ Ethanol/ } \\
\mathrm{CH}_{3} \mathrm{COOH} / \mathrm{CH}_{2} \mathrm{Cl}_{2}\end{array}$ & 1 Eqv. NBS & 60 & 63 & 272 \\
\hline & & $\begin{array}{c}\mathrm{CH}_{3} \mathrm{COOH} / \mathrm{CH}_{2} \mathrm{Cl}_{2} / \\
\text { Ethyl acetate }\end{array}$ & $\begin{array}{c}0.5 \text { Eqv. DDH- } \\
\text { AIBN }\end{array}$ & 55 & 52 & 272 \\
\hline & & $\mathrm{CH}_{3} \mathrm{COOH}$ & 1 Eqv. PBPB & 60 & 57 & 246 \\
\hline Entry & Substrate & Solvents & $\begin{array}{l}\text { Reaction } \\
\text { condition }\end{array}$ & \multicolumn{2}{|c|}{$\begin{array}{l}\text { Method B } \\
\text { (Microwave) } \\
\text { Time Yield (in } \\
\text { Min) (in\%) }\end{array}$} & $\begin{array}{l}\text { M.P. } \\
\left({ }^{0} \mathrm{C}\right)\end{array}$ \\
\hline \multirow[t]{6}{*}{2} & \multirow{6}{*}{ 7-hydroxy-4-methyl-benzopyron-2-one } & $\mathrm{CH}_{3} \mathrm{COOH}$ & $1 \mathrm{Eqv} \cdot \mathrm{Br}_{2}$ & 2 & 52 & 246 \\
\hline & & $\mathrm{CH}_{2} \mathrm{Cl}_{2} / \mathrm{CH}_{3} \mathrm{COOH}$ & $\begin{array}{c}\text { 1Eqv. } \mathrm{HBr}- \\
\mathrm{H}_{2} \mathrm{O}_{2}\end{array}$ & 3 & 67 & 246 \\
\hline & & $\begin{array}{c}\text { THF / Ethyl } \\
\text { acetate/Acetonitrile }\end{array}$ & 1 Eqv. TBATB & 3 & 63 & 272 \\
\hline & & $\begin{array}{l}\text { Ethyl acetate/ Ethanol/ } \\
\mathrm{CH}_{3} \mathrm{COOH} / \mathrm{CH}_{2} \mathrm{Cl}_{2}\end{array}$ & 1 Eqv. NBS & 2 & 67 & 272 \\
\hline & & $\begin{array}{c}\mathrm{CH}_{3} \mathrm{COOH} / \mathrm{CH}_{2} \mathrm{Cl}_{2} / \\
\text { Ethyl acetate }\end{array}$ & $\begin{array}{c}0.5 \text { Eqv. DDH- } \\
\text { AIBN }\end{array}$ & 2 & 61 & 272 \\
\hline & & $\mathrm{CH}_{3} \mathrm{COOH}$ & 1 Eqv. PBPB & 3 & 52 & 246 \\
\hline
\end{tabular}


${ }^{1} \mathrm{H}$ NMR Analysis of S1:- In ${ }^{1} \mathrm{H}$ NMR spectrum of S1, the signal around $\delta 2.23$ was assigned to $\mathrm{C}-4$ methyl group which is at vinylic position (direct attachment to double bond). The signal at $\delta 5.90$ was assigned to $\mathrm{C}-3$ olefinic proton. The signal at $\delta 6.87$ appeared as doublet integrating for one proton with coupling constant $\mathrm{J}=8.4 \mathrm{~Hz}$ (ortho coupling) was assigned to $\mathrm{C}$ - 5 aromatic proton. The signal resonating at $\delta 7.5$ appeared as doublet with $\mathrm{J}=2.0 \mathrm{~Hz}$ (meta coupling) was assigned to $\mathrm{C}-8$ aromatic proton. The signal at $\delta$ 7.65 appeared as double doublet with $\mathrm{J}=8.4 \mathrm{~Hz}$ and $2.0 \mathrm{~Hz}$ integrating for one proton for ortho and meta coupling respectively. The broad singlet appeared as a hump at $\delta 9.8$ was assigned labile $-\mathrm{OH}$ group was further confirmed by $\mathrm{D}_{2} \mathrm{O}$ exchange technique.

${ }^{1} \mathrm{H}$ NMR Analysis of 1a :- In ${ }^{1} \mathrm{H}$ NMR spectrum of 1a, the signal at $\delta 3.22$ was assigned $-\mathrm{CH}_{2} \mathrm{Br}$ group. This is due to bromination of $-\mathrm{CH}_{3}$ to $-\mathrm{CH}_{2} \mathrm{Br}$ group by brominating agent. This is due to introduction of electronegative group results in deshielding of methyl protons as well as its direct attachment to double bond. The signal at $\delta 6.04$ was assigned to $C-$ 3 olefinic proton. The signal at $\delta 6.88$ appeared as doublet integrating for one proton with coupling constant $\mathrm{J}=8.6 \mathrm{~Hz}$ (ortho coupling) was assigned to $\mathrm{C}$ - 5 aromatic proton. The signal resonating at $\delta 7.54$ appeared as doublet with $\mathrm{J}=2.0 \mathrm{~Hz}$ (meta coupling) was assigned to $\mathrm{C}-8$ aromatic proton. The signal at $\delta$ 7.7 appeared as double doublet with $\mathrm{J}=8.3 \mathrm{~Hz}$ and $2.0 \mathrm{~Hz}$ integrating for one proton for ortho and meta coupling respectively. The broad singlet appeared as a hump at $\delta 10.11$ was assigned labile - $\mathrm{OH}$ group was further confirmed by $\mathrm{D}_{2} \mathrm{O}$ exchange technique.

${ }^{1} \mathrm{H}$ NMR Analysis of $1 \mathrm{~b}:-$ In ${ }^{1} \mathrm{H}$ NMR spectrum of $1 \mathrm{~b}$, the signal at $\delta 2.44$ was assigned to $C$ - 4 methyl group attached to olefinic bond. The absence of signal at $\delta 5.9-6.04$ rules out the possibility of any olefinic proton and enhances the possibility of bromination at
C -3 position. The signal at $\delta 6.87$ appeared as doublet integrating for one proton with coupling constant $\mathrm{J}=8.6 \mathrm{~Hz}$ (ortho coupling) was assigned to $\mathrm{C}$ - 5 aromatic proton. The signal resonating at $\delta 7.5$ appeared as doublet with $\mathrm{J}=2.0 \mathrm{~Hz}$ (meta coupling) was assigned to $\mathrm{C}-8$ aromatic proton. The signal at $\delta$ 7.7 appeared as double doublet with $\mathrm{J}=8.4 \mathrm{~Hz}$ and $2.0 \mathrm{~Hz}$ integrating for one proton for ortho and meta coupling respectively. The broad singlet appeared as a hump at $\delta 10.11$ was assigned labile $-\mathrm{OH}$ group was further confirmed by $\mathrm{D}_{2} \mathrm{O}$ exchange technique.

${ }^{1} \mathrm{H}$ NMR Analysis of 1c :- In ${ }^{1} \mathrm{H}$ NMR spectrum of 1c, the signal at $\delta 2.34$ was assigned $\mathrm{C}-4$ methyl group which is attached to olefinic bond. The signal at $\delta$ 6.10 was assigned to $C-3$ olefinic proton. The signal at $\delta 6.87$ appeared as doublet integrating for one proton with coupling constant $\mathrm{J}=8.6 \mathrm{~Hz}$ (ortho coupling) was assigned to $\mathrm{C}-5$ aromatic proton. The absence of signal $\delta 7.5$ with no meta coupling indicating the absence of aromatic proton and hence presence of bromine atom at $\mathrm{C}-8$ position. The signal at $\delta 7.7$ appeared as doublet with $\mathrm{J}=8.4 \mathrm{~Hz}$ integrating for one proton for ortho coupling. The broad singlet appeared as a hump at $\delta 10.11$ was assigned labile $-\mathrm{OH}$ group was further confirmed by $\mathrm{D}_{2} \mathrm{O}$ exchange technique.

${ }^{1} \mathrm{H}$ NMR Analysis of 1d :- In ${ }^{1} \mathrm{H}$ NMR spectrum of $1 \mathrm{~d}$, the signal at $\delta 2.29$ was assigned $\mathrm{C}-4$ methyl group which is attached to olefinic bond. The signal at $\delta$ 6.10 was assigned to $C-3$ olefinic proton. The signal at $\delta 7.4$ appeared as a singlet integrating for one proton was assigned to $C-5$ aromatic proton. The absence of signal $\delta 7.5$ with no meta coupling indicating the absence of aromatic proton and hence presence of bromine atom at $\mathrm{C}-8$ position. The absence of signal at $\delta 7.7$ with no ortho and meta coupling indicating the absence of aromatic proton and hence presence of bromine atom at $\mathrm{C}-6$ position. 
The broad singlet appeared as a hump at $\delta 11.2$ was assigned labile - $\mathrm{OH}$ group was further confirmed by $\mathrm{D}_{2} \mathrm{O}$ exchange technique. However, the introduction of bromine atom (bromination study) in a resultant molecule is well confirmed by mass spectrum analysis.

From the aforesaid study, it is clear that the outcome of the mediated solvent-free bromination reaction depends critically on the electronic nature and location of the substituents. This was further corroborated from the fact that coumarins bearing electron-withdrawing substituents remained unaffected under the applied reaction conditions.

The bromination of titled compound was reported by (Rehman et. al., 2015) using liquid bromine and NBS with limited scope. In this paper herein we report detailed bromination study using liquid $\mathrm{Br}_{2}$, organic bromides, $\mathrm{NBS}, \mathrm{HBr}-\mathrm{H}_{2} \mathrm{O}_{2}$ and $\mathrm{DDH}$ as brominating agent under different protic and aprotic solvents. The efficacy of the bromination of benzopyran under classical method and microwave irradiation has been established.

\section{Study of Solvent}

The effect of the solvent was studied and it was found that the more polar solvents enhance the reactivity of brominating agent to favour side chain bromination. Ethyl acetate found to be a good solvent for regioselective bromination of coumarin with NBS, DDH and TBATB. Benzopyran and its derivatives was brominated under microwave irradiation gave regioselective brominated compound at conjugate double bond at $\mathrm{C}_{3}-\mathrm{H}$ and ring bromination. Polar protic solvents increases yields with good selectivity.

From the aforesaid study it is clear that differentially substituted coumarins undergo transformations involving vinylic bromination and/or ring bromination, which are critically dictated by the electronic nature and location of the substituents. A plausible mechanism has been proposed to rationalize the electronic and positional effects of the substituents on the course of the reaction. The ability of the substituents to stabilize the electron-deficient centers seems to play the most crucial role in determining the reactivity and orientation of the said reaction.

\section{Biological Activity}

Antibacterial Activity using ditch plate method ${ }^{15 a, b}$ (Mwambete and Al lafi et. al.) :- The synthesized molecules were screened for their antibacterial activity at $100 \mu \mathrm{g} / \mathrm{ml}$ concentration using ditch plate method against Gram positive (Staphylococcus aureus) and Gram negative (Escherichia coli) bacterial species qualitatively. The results of the antibacterial activities are summarized in Table 2.

Theory : Ditch plate method is the method of chosen to test the anti-bacterial activity of compounds. It is a preliminary method to screen the anti-microbial potential of compounds / drugs, which are insoluble or partially soluble in aqueous phase. In this method, the test compound is seeded in an agar plate and the test organisms are streaked across to test the inhibition of the growth as a marker of antimicrobial activity.

PROCEDURE : A ditch $(10 \mathrm{~mm} \times 70 \mathrm{~mm})$ is cut into sterile $\mathrm{MH}$ agar plate. The test drug / compound is added to $5 \mathrm{ml}$ molten $\mathrm{MH}$ agar butt at $40^{\circ} \mathrm{C}$ and this mixture is poured into the ditch and allowed to solidify. The ditch should be made in level with the rest of the agar by pouring the mixture. The different bacterial cultures are streaked perpendicular to the ditch using nichrome wire loop. The plate is then incubated at $37^{\circ} \mathrm{C}$ for 24 hours. The results are observed as inhibition of bacterial growth on the ditch as well as adjacent to the ditch. 
Table 2 : Antibacterial Activity Results

\begin{tabular}{|c|c|c|c|}
\hline \multirow[b]{2}{*}{$\begin{array}{l}\text { Sr. } \\
\text { No }\end{array}$} & \multirow[b]{2}{*}{$\begin{array}{c}\text { Compound } \\
\text { No. } \\
\end{array}$} & \multicolumn{2}{|c|}{ Antibacterial Activity } \\
\hline & & $\begin{array}{l}\text { Against Gram } \\
\text { - ve bacteria } \\
\text { species } \\
\text { (Escherichia } \\
\text { coli) } \\
\end{array}$ & $\begin{array}{c}\text { Against Gram } \\
\text { +ve bacterial } \\
\text { species } \\
\text { (Staphylococcus } \\
\text { aureus) }\end{array}$ \\
\hline 1 & S1 (Substrate) & + & + \\
\hline 2 & $1 \mathrm{a}$ & + & + \\
\hline 3 & $1 \mathrm{~b}$ & - & - \\
\hline 4 & $1 \mathrm{c}$ & - & - \\
\hline 5 & $1 \mathrm{~d}$ & - & - \\
\hline
\end{tabular}

The above results shows that the starting material (S1) and side chain brominated molecule (1a) have antibacterial activity against both the bacterial cultures. Thus, monobromo derivative (Benzylic bromination, Compound 1a) was potential antibacterial candidate unlike ring brominated compounds $1 \mathrm{~b}, 1 \mathrm{c}$ and $1 \mathrm{~d}$. In depth analysis of these compounds (S1 \& 1a) through structure activity relationship studies would provide further insight and can be an interesting topic of future studies.

\section{III.CONCLUSION}

The above-mentioned protocol avoids the use of molecular bromine, in halogenated or other toxic organic solvents and any kind of toxic catalyst. In this protocol, excess use of toxic bromine can be avoided by using the requisite amount of solid brominating agent through accurate weighing. A stoichiometric amount of $\mathrm{HBr}$ is liberated, but this is less toxic than $\mathrm{Br} 2$ vapours. Thus, synthetically important bromocoumarin and its derivatives used as intermediate for the many synthesis of with remarkable antituberculotic activity or other biologically important molecules can be accessed easily by this simple protocol. Therefore, the aforesaid protocol for the bromination of coumarins helps to minimize the involvement and dispersal of harmful chemicals in the environment. Moreover, NBS DDH and TBATB under solvent-free conditions is a superior reagent for the bromination of coumarins in comparison to bromine in an organic solvent, as shown in table.

NBS reacts with coumarins faster and more efficiently in the absence of solvent and gives monobromo product. Considerable amounts of unidentified byproducts were produced when TBATB and DDH-AIBN were used in organic solvents. Therefore, the yield and purity of the product were depleted and purity of the products as well as the ease of accessibility of the reagent along with procedural simplicity.

The present NBS, DDH-AIBN and TBATB mediated solvent-free and Microwave irradiation reaction provides a very simple, versatile and efficient regioselective bromination of differentially substituted coumarins at allylic position. Whereas the $\mathrm{Br} 2, \mathrm{HBr}-\mathrm{H}_{2} \mathrm{O}_{2}$ and $\mathrm{PBPB}$ at vinylic position. The most significant features of this methodology are (a) good accessibility of the reagent and its stability (b) a stoichiometric amount of reagent can be used by direct weighing, avoiding excess (c) no evolution of hazardous bromine vapor during the reaction (d) the total elimination of the use of toxic organic solvents (e) a simple experimental procedure (g) good control over the outcome of the reaction by varying the amount of reagent. The aforesaid protocol thus provides an improved procedure for the synthesis of useful bromocoumarins having important pharmaceutical, agricultural and other physicochemical properties.

\section{Supporting Information}


All products were characterized by comparison of their ${ }^{1} \mathrm{H}$ NMR, IR, TOF MS ES and elemental analysis. The spectral data of representative compounds are given below.

\section{Supporting Information}

All products were unambiguously characterized by ${ }^{1} \mathrm{H}$ NMR, TOF MS ES, IR and elemental analysis. The spectral data for some selected representative compounds are given below:

Compound S1. (CDCl $3+$ DMSO-d6, $400 \mathrm{MHz}) \delta$ ppm :2.23 (s, 3H, $\left.-\mathrm{CH}_{3}\right), 5.90$ (S,1H, olefinic proton), 6.87 (d, J = 8.6 Hz, 1H, ArH, ortho coupling), 7.5 (d, J = 2.0 $\mathrm{Hz}, 1 \mathrm{H}, \mathrm{ArH}$, meta coupling), 7.65 (dd, J = 8.4 Hz, 2.0 $\mathrm{Hz}, 1 \mathrm{H}, \mathrm{ArH}$, ortho and meta coupling), $9.8(1 \mathrm{H},-\mathrm{OH}$, $\mathrm{D}_{2} \mathrm{O}$ exchangeable); Formula Weight : 176; Molecular formula : $\mathrm{C}_{10} \mathrm{H}_{8} \mathrm{O}_{3}$; Pure white shining needle shaped solid; Elemental analysis calcd. C 68.18 \% H $4.58 \%$ O $27.25 \%$ found C $68.22 \%$ H $4.54 \%$ O $27.27 \%$; IR $(\mathrm{KBr}) \mathrm{cm}^{-1}$ :- 3442(-OH), 3000 - 2800 (methyl, methylene and methine ), 1670 ( $>\mathrm{C}=\mathrm{O}$ carbonyl group), 1542 (tri-substituted olefinic bond).

Compound 1a. $\left(\mathrm{CDCl}_{3}+\mathrm{DMSO}_{-\mathrm{d}}, 400 \mathrm{MHz}\right) \delta_{\mathrm{ppm}}:-$ 3.77 (s, 2H, $\left.-\mathrm{CH}_{2} \mathrm{Br}\right), 6.04$ ( $\mathrm{S}, 1 \mathrm{H}$, olefinic proton), $6.88(\mathrm{~d}, \mathrm{~J}=8.6 \mathrm{~Hz}, 1 \mathrm{H}, \mathrm{ArH}$, ortho coupling), 7.54 (d, $\mathrm{J}=2.0 \mathrm{~Hz}, 1 \mathrm{H}$, ArH, meta coupling), 7.7 (d, J = 8.3 $\mathrm{Hz}, 2.0 \mathrm{~Hz}, 1 \mathrm{H}, \mathrm{ArH}$, ortho and meta coupling), 10.11 (brs, $1 \mathrm{H},-\mathrm{OH}, \mathrm{D}_{2} \mathrm{O}$ exchangeable); Formula Weight : 255; Molecular Formula : $\mathrm{C}_{10} \mathrm{H}_{7} \mathrm{BrO}_{3}$; Pure white shining needle shaped solid. Elemental analysis, calcd. C $47.09 \%$ H $2.77 \%$ O $18.82 \%$ Br $31.33 \%$ found C $47.05 \%$ H $2.74 \%$ O $18.85 \%$; IR (KBr) cm cm $^{-1}$ 3502($\mathrm{OH}), 3147\left(-\mathrm{CH}_{3}\right), 1694$ ( $>\mathrm{C}=\mathrm{O}$, carbonyl group), 1533 (tri-substituted olefinic bond), 606 (-Br).

Compound 1b. $\left(\mathrm{CDCl}_{3}+\mathrm{DMSO}_{-} \mathrm{d}_{6}, 400 \mathrm{MHz}\right) \delta_{\mathrm{ppm}}:-$ $2.44\left(\mathrm{~s}, 3 \mathrm{H},-\mathrm{CH}_{3}\right), 6.87(\mathrm{~d}, \mathrm{~J}=8.6 \mathrm{~Hz}, 1 \mathrm{H}, \mathrm{ArH}$, ortho coupling), 7.5 (d, J = $2.0 \mathrm{~Hz}, 1 \mathrm{H}, \mathrm{ArH}$, meta coupling), 7.7 (dd, J = 8.4 Hz, $2.0 \mathrm{~Hz}, 1 \mathrm{H}$, ArH, ortho and meta coupling), 10.11 (brs $1 \mathrm{H},-\mathrm{OH}, \mathrm{D}_{2} \mathrm{O}$ exchangeable); Formula Weight : 255. Mol. Formula : $\mathrm{C}_{10} \mathrm{H}_{7} \mathrm{BrO}_{3}$; Pure white shining needle shaped solid. Elemental analysis, calcd. C $47.09 \% \mathrm{H} 2.77 \% \mathrm{O} 18.82 \% \mathrm{Br}$ $31.33 \%$ found C $47.06 \%$ H $2.76 \%$ O $18.85 \%$; IR $(\mathrm{KBr}) \mathrm{cm}^{-1}$ :- $3449(-\mathrm{OH}), 3162\left(-\mathrm{CH}_{3}\right), 1701$ ( >C=O, carbonyl group), 1605 (tetra-substituted olefinic bond), 611(-Br).

Compound 1c. $\left(\mathrm{CDCl}_{3}+\mathrm{DMSO}_{-} \mathrm{d}_{6}, 400 \mathrm{MHz}\right) \delta_{\mathrm{ppm}}:-$ $2.34\left(\mathrm{~S}, 3 \mathrm{H},-\mathrm{CH}_{3}\right), 6.10$ (s, 1H, olefinic proton), 6.87 (d, J = 8.6 Hz, 1H, ArH, ortho coupling), 7.7 (d, J = 8.4 $\mathrm{Hz}, 1 \mathrm{H}, \mathrm{ArH}$, ortho coupling), 10.11 (brs, $1 \mathrm{H},-\mathrm{OH}$, $\mathrm{D}_{2} \mathrm{O}$ exchangeable); Formula Weight : 255. Molecular Formula : $\mathrm{C}_{10} \mathrm{H}_{7} \mathrm{BrO}_{3}$; Pure white shining needle shaped solid. Elemental analysis, calcd. C $47.09 \% \mathrm{H}$ 2.77\% O 18.82 \% Br 31.33\% found C $47.06 \%$ H $2.76 \%$ O $18.85 \%$; IR (KBr) cm ${ }^{-1}$ :- $3475(-\mathrm{OH}), 3147\left(-\mathrm{CH}_{3}\right)$, 1693 ( $>\mathrm{C}=\mathrm{O}$, carbonyl group), 1554 (tri-substituted olefinic bond), 605(-Br).

Compound 1d. $\left(\mathrm{CDCl}_{3}+\mathrm{DMSO}_{-} \mathrm{d}, 400 \mathrm{MHz}\right) \delta_{\mathrm{ppm}}:-$ 2.29 (s, 3H, - $\mathrm{CH}_{3}$ ), 6.10 (s, $1 \mathrm{H}$, olefinic proton), 7.4 (s, 1H, ArH); Formula Weight : 412. Molecular Formula : $\mathrm{C}_{10} \mathrm{H}_{5} \mathrm{Br}_{3} \mathrm{O}_{3}$; Pure yellow flakes. Elemental analysis, calcd. C $29.09 \%$ H $1.22 \%$ O $11.63 \%$ Br $58.06 \%$ found C $29.10 \% \mathrm{H} 1.25 \% \mathrm{O} 11.66 \%$; IR $(\mathrm{KBr}) \mathrm{cm}$ 1 :- $3502(-\mathrm{OH}), 3198\left(-\mathrm{CH}_{3},-\mathrm{CH}\right), 1703(>\mathrm{C}=\mathrm{O}$, carbonyl group), 1601(olefinic group), 709(-Br).

Experimental : Melting points were determined on a Thomas Hoover capillary melting point apparatus using digital thermometer. IR spectra were recorded on a Shimadzu FTIR Prestige model as $\mathrm{KBr}$ pellet. ${ }^{1} \mathrm{H}$ NMR spectra were recorded on a Varian $400 \mathrm{MHz}$ spectrometer in $\mathrm{CDCl}_{3}$. Chemical shifts were recorded in parts per million down field from tetramethyl silane. Mass spectra were recorded on a 
TOF MS ES mass spectrometer. Elemental analysis were carried out as a percentage on a Thermo finnigan, Flash EA 1112 series, Italy.

\section{CHROMATOGRAPHIC SYSTEM}

Column chromatography : For column chromatography 100 - 200 mesh Acme grade silica gel is used. The crude reaction mixture is concentrated under reduced pressure to yield crude mass which is preadsorbed on silica gel and purified by column chromatography with increase in concentration of Ethyl acetate in Petroleum ether. The fractions having similar 'rf' values were pooled together, concentrated and subjected for characterization using various spectroscopic techniques.

Thin layer chromatography : TLC plates were prepared using silica gel G (ACME, BOMBAY). Pet. ether: EtOAc ( $85: 15)$ was used as the solvent system. Radial chromatography : The circular glass plates of thickness $1 \mathrm{~mm}$, were prepared by using silica gel (PF254, E. MERCK, $50 \mathrm{~g}$ ) in cold distilled water (105 $\mathrm{ml})$. For elution, gradually increasing concentrations of EtOAc in pet ether were employed.

\section{ACKNOWLEDGEMENTS}

I, Mr. Ajaykumar C. Singh want to express sincere thanks to Dr. Vijay D. Gangan of the Thakur College of Science \& Commerce and Dr. Nitin Joshi for their invaluable assistance and support in the course of this investigation.

\section{REFERENCES}

[1]. Kumar, S., saini, A., Sandhu, J. S. (2007). LiBrMediated, solvent free von Pechmann reaction : facile and efficient method for the synthesis of 2H-chromen-2-ones. ARKIVOC, XV, pp. 18 23.

[2]. Lin, C. M., Huang, S. T., Lee, F. W., Sawkuo, H., Lin, M. H. (2006). 6-Acyl-4-aryl /alkyl-5,7dihydroxycoumarins as anti-inflammatory agents. Bioorganic \& Medicinal Chemistry, 14 (13), pp. 4402 - 4409.

[3]. Bhat, M. A., Siddiqui, N., Khan, S. A. (2006). Synthesis of novel thioureido derivatives of sulfonamides and thiosemicarbazido derivatives of coumarin as potential anticonvulsant and analgesic agents. Indian J. Pharm. Sci., 68 (1), pp. 120 - 123.

[4]. Massimo,C., Francesco, E., Federica, M., Carla, M. M., Prieto, G. S., Carlos, R. J. (2003).

[5]. Synthesis of Collinin, an antiviral coumarin. Aust. J. Chem., 2003, 56 (1), pp. 59 - 60.

[6]. Ruszat, R., Wyler, S., Forster, T., Reich, O., Christian, G. S., Thomas, C. G., Sulser, T. and Bachmann, A. (2007). Safety and effectiveness of photoselective vaporization of the prostate (PVP) in patients on ongoing oral anticoagulation. Eur. Urol., 51, pp. 1031 -10 41.

[7]. Tyagi, A. K, Raj, H. G, Vohra, P., Gupta, G., Kumari, R., Kumar, P., Gupta, R. K. (2003). Synthesis of novel amino and acetyl amino-4methylcoumarins and evaluation of their antioxidant activity. Eur J.Med. Chem, 40 (4), pp. $413-420$.

[8]. Modranka, J. N., Nawrot, E., Graczyk, J. (2006). In vivo antitumor, in vitro antibacterial activity and alkylating properties of phosphorohydrazine derivatives of coumarin and chromone. Eur. J. Med. Chem., 41 (11), pp. 1301 - 1309.

[9]. Sardari, S., Mori, Y., Horita, K., Micetich, R.G., Nishibe, S., Daneshtalab, M. (1999). Synthesis and antifungal activity of coumarins and 
angular furanocoumarins. Bioorg. Med.Chem., 7, pp. 1933 - 1940.

[10]. a) Huang, Li., Yuan, X., Yu, D., Lee, K. H., Chen, C. H. (2005). Mechanism of action and resistant profile of anti-HIV-1 coumarin derivatives. Virology, 332 (2), pp. 623 - 628. b) Hussien, F. A., Keshe, M., Alzobar, K., Merza, J., Karam, A. (2016). Synthesis and Nitration of 7-Hydroxy-4-Methyl Coumarin via Pechmann Condensation Using Eco-Friendly Medias International letters of Chemistry, Physics and Astronomy, 69, pp. 66 - 73.

[11]. Elinos-Baez, C. M., Leon, ,F., Santos, E. (2005). Effects of coumarin and 7-OH-coumarin on bcl-2 and Bax expression in two human lung cancer cell lines in vitro. Cell. Biol. Int., 29, pp. $703-708$.

[12]. Mohanty, N., Rath, P. C., Rout, M. K.. (1967). J. Indian Chem. Soc., 44, pp. 1001 - 1004.

[13]. Kennedy, R. O. and Tharnes, R. D. (1997). Coumarins : Biology, Application and Mode of Action, Wiley \& Sons, Chichester.

[14]. Murray, R. D. H.; Mendez, J.; Brown (1982). The Natural Coumarins: Occurrence, Chemistry and Biochemistry, Wiley and Sons, New York S. A.

[15]. Singh, A. C, Joshi, R. N., Pujari, J. S., Satpute, S. M., Gangan V. D., Dubey, R. S., Chakraborty, C. T. (2017). Green synthesis : Bromination study of 7-Hydroxy-4-methylcoumarin with $\mathrm{Na}-\mathrm{Y}$ type Zeolite without toxic solvents. Journal of Science \& Technology - BIONANO FRONTIER, Vol 10 (1), pp. 1 - 4, January - June 2017.

[16]. a)Mwambete K. D. and Lyombe F. (2011). Antimicrobial activity of medicated soaps commonly used by Dar es Salaam residents in Tanzania. Indian J. Pharm. Sci., 73 (1) : 92 - 98. b ) Al lafi T. and Ababneh H. (1995). The effect of miswak used in Jordan and Middle East on oral bacteria. International Dental Journal, 45 (3), pp. 218 - 222.

\section{Cite this article as :}

Vijay D. Gangan, Ajaykumar C. Singh, Ruchira Joshi, Amod V. Tamhankar, Kalpana J. Bhatwadekar, Shyamlal T. Yadav, Suyog S. Daye Dattatraya A. Dute, Sakharam K. Godage, Manoj Yewale, Gaurav Pimple, Arjun L. Ghorpade, "A Detailed Bromination Study of 7-Hydroxy-4-Methyl Benzopyran-2-One Under Classical Method and Microwave Irradiation", International Journal of Scientific Research in Science and Technology (IJSRST), Online ISSN : 2395-602X, Print ISSN : 2395-6011, Volume 6 Issue 2, pp. 205-213, March-April 2019. Available at doi : https://doi.org/10.32628/IJSRST1196231 Journal URL : http://ijsrst.com/IJSRST1196231 